\title{
A revision of Rhizobium Frank 1889, with an emended description of the genus, and the inclusion of all species of Agrobacterium Conn 1942 and Allorhizobium undicola de Lajudie et al. 1998 as new combinations: Rhizobium radiobacter, $R$. rhizogenes, $R$. rubi, $R$. undicola and $R$. vitis
}

\author{
J. M. Young, ${ }^{1}$ L. D. Kuykendall, ${ }^{2}$ E. Martínez-Romero, ${ }^{3}$ A. Kerr ${ }^{4}$ \\ and H. Sawada ${ }^{5}$
}

Author for correspondence: L. D. Kuykendall. Tel: +1 301504 7072. Fax: + 13015045449.
e-mail: dkuykend@asrr.arsusda.gov

1 Landcare Research, Private Bag 92170, Auckland, New Zealand

2 Plant Sciences Institute, Beltsville Agricultural Research Center, USDAARS, 10300 Baltimore Ave, Beltsville, MD 20705, USA

3 Centro de Investigación sobre Fijación de Nitrógeno, UNAM. AP 565-A, Cuernavaca, Morelos, Mexico

4419 Carrington Street, Adelaide, South Australia 5000, Australia

5 National Institute of AgroEnvironmental Sciences, 3-1-1 Kannondai, Tsukuba, Ibaraki 305-8604, Japan

\begin{abstract}
Rhizobium, Agrobacterium and Allorhizobium are genera within the bacterial family Rhizobiaceae, together with Sinorhizobium. The species of Agrobacterium, Agrobacterium tumefaciens (syn. Agrobacterium radiobacter), Agrobacterium rhizogenes, Agrobacterium rubi and Agrobacterium vitis, together with Allorhizobium undicola, form a monophyletic group with all Rhizobium species, based on comparative 16S rDNA analyses. Agrobacterium is an artificial genus comprising plant-pathogenic species. The monophyletic nature of Agrobacterium, Allorhizobium and Rhizobium and their common phenotypic generic circumscription support their amalgamation into a single genus, Rhizobium. Agrobacterium tumefaciens was conserved as the type species of Agrobacterium, but the epithet radiobacter would take precedence as $R$ hizobium radiobacter in the revised genus. The proposed new combinations are Rhizobium radiobacter, Rhizobium rhizogenes, Rhizobium rubi, Rhizobium undicola and Rhizobium vitis.
\end{abstract}

Keywords: Rhizobiaceae, phenetic, phylogenetic, polyphasic, taxonomy

\section{INTRODUCTION}

Nitrogen-fixing bacteria that form symbiotic associations with members of the Leguminosae, and related pathogenic bacteria, have been ascribed to the genera Agrobacterium Conn 1942, Allorhizobium de Lajudie et al. 1998b, Azorhizobium Dreyfus et al. 1988, Bradyrhizobium Jordan 1982, Mesorhizobium Jarvis et al. 1997, Phyllobacterium Knösel 1984, Rhizobium Frank 1889 and Sinorhizobium Chen et al. 1988. For some time, it has been clear that the nomenclature of Rhizobium and related genera does not accurately describe their natural classification and is in need of

Abbreviations: ITS, internal transcribed spacer; LBP, local bootstrap probability; $M E$, minimum-evolution; $M L$, maximum-likelihood; $M P$, maximum-parsimony; $\mathrm{N}$, neighbour-joining. revision (Kersters \& De Ley, 1984; Willems \& Collins, 1993; Sawada et al., 1993b; de Lajudie et al., 1998b). In this paper, the relevant literature is reviewed and a nomenclature is proposed that aims to reflect, as closely as possible, the natural polyphasic and phenetic relationships of these taxa.

The original species nomenclature

The nomenclature of Rhizobium species was originally shaped by the belief that a natural classification could be based on the specificity of symbiotic plant range of bacterial strains and species. The recognition that nodulation and specificity were characters of strains carrying particular Sym plasmids, reviewed by Martínez-Romero \& Palacios (1990), and therefore were taxonomically unreliable, has led to the aban- 
donment of this concept. In Rhizobium species, nonsymbiotic strains have been reported for different species (Jarvis et al., 1989; Laguerre et al., 1993; Segovia et al., 1991; Soberón-Chávez \& Nájera, 1989), indicating that symbiotic plasmids can be lost in nature and are not essential for bacterial survival. Furthermore, functional plasmids can be transferred between members of Rhizobium and Agrobacterium species (Abe et al., 1998; Hooykaas et al., 1977; Martínez et al., 1987). Overviews of the relationships of bacterial nitrogen-fixing genera are given in Young (1994), Young \& Haukka (1996) and Martínez-Romero \& Caballero-Mellado (1996).

When they first proposed the names Agrobacterium tumefaciens and Agrobacterium rhizogenes, Smith \& Townsend (1907) and Riker et al. (1930) followed the custom of giving names that reported a distinctive character of the species, in this case their pathogenic symptoms. Agrobacterium tumefaciens (Smith and Townsend 1907) Conn 1942 (type species) was the name given to strains of Agrobacterium capable of inducing tumorigenic reactions in a wide range of host plant species, although some of these tumorigenic strains isolated from Vitis spp. appeared to be specific to grape. Agrobacterium rhizogenes (Riker et al. 1930) Conn 1942 comprised strains capable of inducing a hairy-root (rhizogenic) reaction in host plants. Agrobacterium rubi (Hildebrand 1940) Starr and Weiss 1943 referred to strains capable of inducing tumorigenic reactions in the canes of Rubus spp. and appeared to have a relatively limited host range. Recently, the strains specific to Vitis spp., referred to above, were named Agrobacterium vitis Ophel and Kerr 1990. Agrobacterium radiobacter (Beijerinck and van Delden 1902) Conn 1942 comprised non-pathogenic Agrobacterium strains. Although Holmes \& Roberts (1981) offered an alternative classification, the application of the names Agrobacterium rhizogenes and Agrobacterium tumefaciens on the basis of distinct pathogenic characters was supported by Kersters \& De Ley (1984) and has since been used by many workers (examples are Jarvis et al., 1986; Sawada et al., 1992, 1993b; Weibgen et al., 1993; Bouzar et al., 1993).

\section{Present classification of the family Rhizobiaceae}

The rhizobia. A number of revisions and additions to the taxonomy of rhizobia (family Rhizobiaceae) have been made in the past 20 years. The Approved Lists of Names of Bacteria (Skerman et al., 1980) recorded in the genus Rhizobium all then-known bacteria capable of nodulation and nitrogen fixation in symbiotic relationships with plants in the family Leguminosae. Symbiotic species were Rhizobium leguminosarum (type species), Rhizobium japonicum, Rhizobium lupini, Rhizobium meliloti, Rhizobium phaseoli and Rhizobium trifolii. The Agrobacterium species Agrobacterium tumefaciens, Agrobacterium rhizogenes and Agrobacterium rubi and species in Phyllobacterium Knösel 1984 (Phyllobacterium myrsinacearum and Phyllo- bacterium rubiacearum) causing hypertrophies in plants as pathogenic (or oncogenic; meaning 'causing tumours') strains were also included in the family Rhizobiaceae. Since then, revisions have been made at both the generic and specific levels. Based on a summary of clustering analyses of phenotypic characters, DNA-DNA reassociation data and other data, Jordan (1982) revised the symbiotic nitrogen-fixing bacteria into two genera, in which fast-growing, acidproducing strains were retained in Rhizobium and slow-growing, alkali-producing strains were allocated to Bradyrhizobium as Bradyrhizobium japonicum Jordan 1982. Three species in Rhizobium, R. leguminosarum (amalgamating the former species of $R$. leguminosarum, $R$. phaseoli and $R$. trifolii), $R$. meliloti and Rhizobium loti were listed in the first edition of Bergey's Manual of Systematic Bacteriology (Jordan, 1984). Since then, the genus Bradyrhizobium has been shown to be on a phylogenetic branch distant from the Rhizobium species. Two species, Bradyrhizobium elkanii Kuykendall et al. 1993 and Bradyrhizobium liaoningense Xu et al. 1995, and other related slow-growing, symbiotic nitrogen-fixing strains have also been reported within this genus. The genus Azorhizobium, with a single species, Azorhizobium caulinodans, was proposed for stem-nodulating strains from Sesbania rostrata (Dreyfus et al., 1988). This taxon is also distantly related to other taxa with hypertrophying capabilities.

Other significant revisions have been made to taxa closely related to, and including, Rhizobium species. Chen et al. (1988) proposed a separate genus, Sinorhizobium, to include Rhizobium fredii Scholla and Elkan 1984 and the new species Sinorhizobium xinjiangense Chen et al. 1988. Subsequently, R. meliloti was transferred to the genus (de Lajudie et al. 1994) and Sinorhizobium sahelense de Lajudie et al. 1994, Sinorhizobium terangae de Lajudie et al. 1994, Sinorhizobium medicae Rome et al. 1996 and Sinorhizobium arboris and Sinorhizobium kostiense (Nick et al., 1999) have been proposed as new species. $R$. loti and some other recently described Rhizobium species are distinguished from Rhizobium and Sinorhizobium by comparative $16 \mathrm{~S}$ rDNA sequence data, in having a slower growth rate (indicating underlying metabolic differences) and by a distinct fatty acid profile (Jarvis et al., 1996). For the species, Jarvis et al. (1997) proposed a new genus, Mesorhizobium, to include Mesorhizobium loti (type species), Mesorhizobium ciceri Nour et al. 1994, Mesorhizobium huakuii Chen et al. 1991, Mesorhizobium mediterraneum Nour et al. 1995 and Mesorhizobium tianshanense Chen et al. 1995. Mesorhizobium amorphae Wang et al. 1999 and Mesorhizobium plurifarium de Lajudie et al. 1998a are new species in the genus. Recently, a genus containing a single species, Allorhizobium undicola de Lajudie et al. 1998 b, has been proposed for a population of nodulating, nitrogen-fixing strains that are more closely related to pathogenic Agrobacterium species than other nodulating Rhizobium species by comparative 
sequence analysis of $16 \mathrm{~S}$ rDNA. As well as these new genera, eight new species have been proposed within the genus Rhizobium: Rhizobium etli Segovia et al. 1993, Rhizobium galegae Lindström 1989, Rhizobium gallicum Amarger et al. 1997, Rhizobium giardinii Amarger et al. 1997, Rhizobium hainanense Chen et al. 1997, Rhizobium huautlense Wang et al. 1998, R. mongolense van Berkum et al. 1998 and Rhizobium tropici Martínez-Romero et al. 1991.

The agrobacteria. The natural species of the genus Agrobacterium have been investigated using numerical analysis of phenotypic characteristics (White, 1972; Kersters et al., 1973; Holmes \& Roberts, 1981), biochemical and physiological tests (Keane et al., 1970; Kersters et al., 1973; Kerr \& Panagopoulos, 1977; Süle, 1978; Holmes \& Roberts, 1981), fatty acid methyl ester profiles (Jarvis et al., 1996; Sawada et al., 1992), DNA-DNA reassociation (De Ley, 1972, 1974), measurements of the thermal stability of DNA-DNA hybrids (De Ley et al., 1973) and comparison of electrophoregrams of soluble proteins (Kersters \& De Ley, 1975). The results obtained by all methods indicated three genetically and phenotypically distinct groups or clusters, not including Agrobacterium rubi. These groups corresponded to biovars (or biotypes) 1, 2 and 3 of Keane et al. (1970), subsequently recognized as species (Holmes \& Roberts, 1981; Bradbury, 1986; Sawada et al., 1993b). [The term 'biovar' is usually applied to populations distinguished on the basis of their biochemical or physiological properties, distinguished as infrasubspecies (Lapage et al., 1992). In Agrobacterium, it is generally agreed that biovar populations (sensu Keane et al., 1970) have the status of species. In Rhizobium, the term biovar is generally applied to populations within species carrying particular Sym plasmids.] These three species, recognized on the basis of their overall phenotypic and genomic relatedness, are named according to the type strains allocated to each species population. (i) Agrobacterium tumefaciens corresponds to biotype 1 of Keane et al. (1970), group I of White (1972), cluster 1 of Kersters et al. (1973) and biovar 1 of Kersters \& De Ley (1984), Willems \& Collins (1993) and Sawada et al. (1993a). It includes the type strain of Agrobacterium tumefaciens, circumscribed according to its tumorigenic pathogenic characters, as well as the type strain of Agrobacterium radiobacter, a non-pathogenic strain. Agrobacterium tumefaciens is the conserved type species of Agrobacterium and therefore takes precedence over the earlier named Agrobacterium radiobacter (Judicial Commission, 1970). (ii) Agrobacterium rhizogenes corresponds to biotype 2 of Keane et al. (1970), biovar 2 of Kersters \& De Ley (1984), Sawada et al. (1993a) and Willems \& Collins (1993), group III of White (1972) and cluster 2 of Kersters et al. (1973). (iii) Agrobacterium vitis Ophel and Kerr 1990 was proposed as the name for the third biovar (Keane et al., 1970; Kersters \& De Ley, 1984, biotype 3; Kerr \& Panagopoulos, 1977; Süle, 1978; Panagopoulos et al., 1978). Agrobacterium vitis is found mainly on grapes but strains of this species have also been isolated from Actinidia spp. (Sawada \& Ieki, 1992b). Agrobacterium rubi is a fourth species characterized in genotypic and phenotypic terms, usually isolated from Rubus spp., although strains have been isolated from other hosts (Bradbury, 1986) and it is capable of infecting a range of plant hosts (Sawada et al., 1992).

Both the natural species Agrobacterium tumefaciens and Agrobacterium rhizogenes, named on the basis of the application of types, are represented by strains that may be either tumorigenic, rhizogenic or non-pathogenic, according to their plasmid complement. Such characters do not offer stable systematic classification at the species level. Though of practical use and widely supported, the special purpose nomenclature based on pathogenicity is inconsistent with the natural classification of Agrobacterium species as now understood.

Agrobacterium is a genus containing plant-pathogenic species closely related to Rhizobium. The amalgamation of these two genera has often been suggested (Graham, 1964; Heberlein et al., 1967; De Ley, 1968; White, 1972; Graham, 1976; Kerr, 1992; Sawada et al., 1993b). In spite of the artificial character of Agrobacterium, the convenience of the conventional nomenclature (described below) and the difficulty in applying species names to the plant pathogens without ambiguity seem to have been the reasons for the failure to make formal revisions.

Allorhizobium. de Lajudie et al. (1998b) proposed the name Allorhizobium (meaning other Rhizobium) for a monospecific genus, comprising the nitrogen-fixing species Allorhizobium undicola, established on the basis of comparative analysis of $16 \mathrm{~S}$ rDNA sequence data that showed the organism as an outlying branch of the Agrobacterium-Rhizobium cluster. Its nearest neighbour is Agrobacterium vitis. Considering the description of Allorhizobium undicola, it is well supported as a species distinct from Agrobacterium vitis (and from all other members of Agrobacterium-Rhizobium) by DNA-DNA reassociation data, SDS-PAGE of proteins, PCR-RFLP of the internal transcribed spacer (ITS) region between the $16 \mathrm{~S}$ and $23 \mathrm{~S}$ rDNA and nutritional data. However, inspection of SDS-PAGE, ITS and nutritional data give no support for a closer relationship between Agrobacterium vitis and Allorhizobium undicola than to other species in Agrobacterium, Rhizobium, Sinorhizobium or Mesorhizobium. The generic relationships proposed between these species are therefore based entirely on the comparative $16 \mathrm{~S}$ rDNA sequence data; on a perceived low percentage similarity value $(95.5 \%)$ and the lack of bootstrap support for the branch. The reasons that de Lajudie et al. (1998b) gave for proposing the new genus were the unsettled state of Agrobacterium nomenclature and the evidence of heterogeneity in Rhizobium, which implied the need for the creation of a new genus separate from Agrobacterium and Rhizobium. However, Allorhizobium undicola shares a common generic circumscription with Agrobacterium 


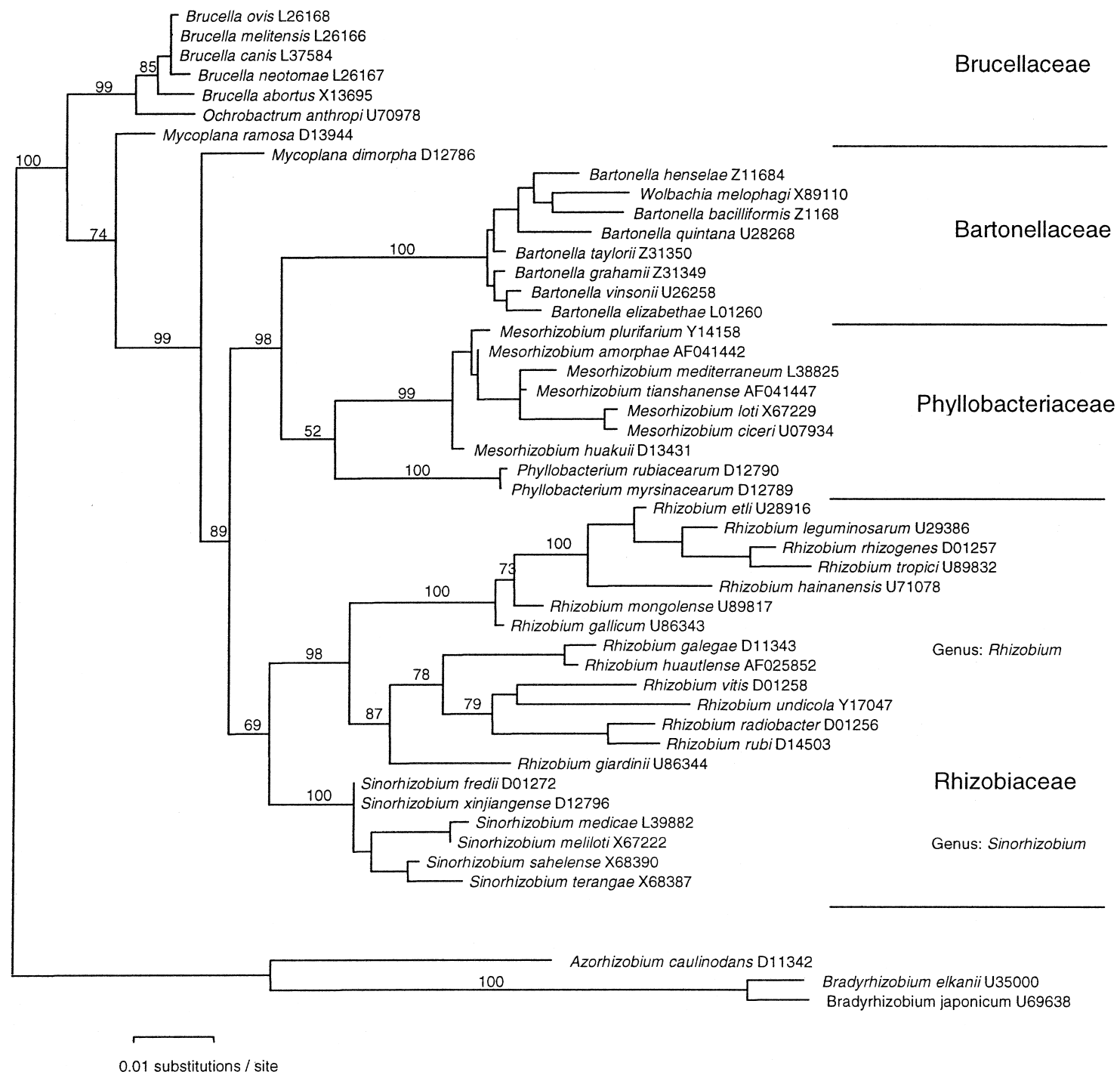

Fig. 1. Maximum-likelihood tree expressing the relationships among the Rhizobiaceae and their relatives, based on $16 \mathrm{~S}$ rDNA sequences. Horizontal branch lengths are proportional to the estimated number of nucleotide substitutions and local bootstrap probabilities (as percentages) were determined for 1000 resamplings. Bacterial family names are those recorded on the website of the Bergey's Manual Trust (http://www.cme.msu.edu/Bergeys).

vitis and with all other members of Agrobacterium and Rhizobium (de Lajudie et al., 1998b). Acceptance of sequence data alone based on the neighbour-joining analysis presented by de Lajudie et al. (1998b) as justification for the proposal of Allorhizobium invites reclassification of the outlying group of Rhizobium species and of Agrobacterium vitis, according to one of several possibilities: (i) proposal of the genus Allorhizobium to include Allorhizobium undicola, Agrobacterium vitis, $R$. galegae and $R$. huautlense; (ii) amalgamation of Allorhizobium undicola and Agrobacterium vitis in Allorhizobium and the creation of a new genus to recognize $R$. galegae and $R$. huautlense; (iii) proposal of a new genus for Agrobacterium vitis in a new monospecific sister genus with Allorhizobium (and the creation of a new genus to recognize $R$. galegae and $R$. huautlense); or (iv) proposal of monospecific genera for Agrobacterium vitis, R. galegae and
$R$. huautlense. A similar iteration is possible following the ML and NJ analyses reported below. In these, Allorhizobium undicola shares a common branch with Agrobacterium vitis, which could be recognized as a species in the genus Allorhizobium or as a new sister genus. The conservation of Agrobacterium tumefaciens (syn. radiobacter) in the neighbouring branch forbids reclassification of this species, but Agrobacterium rubi could be renamed as a new genus. However, unless reference is made to the generic phenotype (that is to say, in the absence of distinct generic circumscriptions for the proposed genera), there is no rational way to choose between these alternatives. Alternatively, a revision accepting the inferred phylogeny of the taxon but which takes account of the supporting phenotypic data (which shows Allorhizobium undicola to be indistinguishable from Rhizobium) would see this species included in the genus Rhizobium. 


\section{METHODS}

Analysis of 16S rDNA sequence data. Analyses were of 1444 base 16S rDNA sequences of Rhizobium species and species in the related families Phyllobacteriaceae, Bartonellaceae and Brucellaceae, with Bradyrhizobium species and Azorhizobium caulinodans as outlying taxa. Trees were constructed by using four tree-building methods, maximumlikelihood (ML) (Felsenstein, 1981), neighbour-joining (NJ) (Saitou \& Nei, 1987), minimum-evolution (ME) (Rzhetsky $\&$ Nei, 1992) and maximum-parsimony (MP) (Swofford, 1993), as previously described in detail (Sawada et al., 1999).

To determine the ML tree topology, the local rearrangement searches of NucML (contained in the program package MOLPHY version 2.3) (Adachi \& Hasegawa, 1996) were carried out, starting from the NJ tree topology and/or the topology obtained by the quick add OTUs search option as the initial trees. The HKY85 model (Hasegawa et al., 1985) (alpha/beta $=2 \cdot 2 ; \ln L=-6993 \cdot 11$ ) was used for the base substitution process. The resulting tree is shown in Fig. 1.

Evolutionary distances (number of base substitutions) were estimated using the two-parameter method (Kimura, 1980) and the TN93 method (Tamura \& Nei, 1993). Distances were then used to construct the $\mathrm{NJ}$ and $\mathrm{ME}$ trees using CLUSTAL W version 1.8 (Thompson et al., 1994) and MEGA2 (K. Tamura, personal communication), respectively. The tree resulting from the NJ method is shown in Fig. 2. The tree resulting from the $\mathrm{ME}$ method is identical in all essentials to the ML tree and is not shown.

PAUP version 3.1.1 (Swofford, 1993) and MEGA2 (K. Tamura, personal communication) were used for MP analysis and heuristic and branch-and-bound searches were used to ensure finding the most parsimonious trees. When two or more parsimonious trees were obtained, a strict consensus tree and a $50 \%$ majority-rule consensus tree were constructed.

As shown in Fig. 1 (ML tree) and Fig. 2 (NJ tree), the rate of nucleotide substitution differed among lineages. Because estimates based on maximum-parsimony are regarded as misleading when the rate of nucleotide substitution is not constant (Felsenstein, 1978; Hasegawa et al., 1991), the analysis is not shown here, although the topology was almost identical to that of ML tree.

To evaluate the reliability of the inferred ML tree topology, the local bootstrap probability (LBP) was calculated using the RELL method (Adachi \& Hasegawa, 1996; Hasegawa \& Kishino, 1994) with 1000 replications. For the NJ topology, the bootstrap probability (Felsenstein, 1985) was calculated by repeating the bootstrap resampling procedure 1000 times.

\section{RESULTS AND DISCUSSION}

\section{Inferred phylogenetic relationships of the Rhizobiaceae}

In terms of its phylogenetic relationships inferred from comparative sequence analysis of $16 \mathrm{~S}$ rDNA, the family Rhizobiaceae is considered to be relatively closely related to the families Bartonellaceae, Brucellaceae and Phyllobacteriaceae in the $\alpha$-Proteobacteria. This family terminology is that proposed in the forthcoming second edition of Bergey's Manual of Systematic Bacteriology and is presented on the website of the Bergey's Manual Trust (http:// www.cme.msu.edu/Bergeys). Comparative analysis of $16 \mathrm{~S}$ rDNA sequence data indicates that the genera Bradyrhizobium, in the Bradyrhizobiaceae, and Azorhizobium are distantly related to the other symbiotic nitrogen-fixing genera. Most or perhaps all species in the Rhizobiaceae and a number in the Phyllobacteriaceae (Wang et al., 1999; Xu \& Murooka, 1995; Zou et al., 1997) appear to be distinct in their capacity to incorporate large functional plasmids or megaplasmids, which enable them to cause hypertrophies in plants as pathogenic tumours or symbiotic nitrogenfixing nodules. Strains representing the Bartonellaceae, Brucellaceae and Phyllobacteriaceae (Phyllobacterium and Mesorhizobium) are sometimes represented as interspersed between the members of the Rhizobiaceae (de Lajudie et al., 1998a, b; Young \& Haukka, 1996). In the analysis made here (Figs 1 and 2), the inclusion of sequences comprehensively representing the species of Bartonella (family Bartonellaceae) and of Brucella (family Brucellaceae), as well as sequences of other related genera, has resulted in a cladogram with family branches, including the family Phyllobacteriaceae. However, reliance cannot generally be placed on any particular sequence comparison, because analyses give differing results depending on the chosen algorithm and, most particularly, on the selection of included sequences, as shown by comparison of inferred phylogenies in recent reports (Amarger et al., 1997; Chen et al., 1997; de Lajudie et al., 1994, 1998a, b; Jarvis et al., 1997; Nour et al., 1995; Rome et al., 1996; Sawada et al., 1993b; Tan et al., 1997; van Berkum et al., 1998; Wang et al., 1998; Willems \& Collins, 1993). Thus, Willems \& Collins (1993) presented two unrooted phylogenetic trees in which the closer relationship of Sinorhizobium to Rhizobium or to Mesorhizobium depended upon whether an algorithmic or a parsimonious analysis was conducted. A similar result was reported by Laguerre et al. (1997) using mapped restriction site polymorphisms of $16 \mathrm{~S}$ rDNA. It is noted here that, while high bootstrap values give confidence for some branches, such values do not indicate whether taxa are closely or distantly related. Also, low bootstrap values mean only that data are inadequate or not reliable for the purposes of inference. They do not mean, as is sometimes implied, that taxa under consideration are necessarily not closely related. In this study, the bootstrap values for the node linking the two Rhizobium/Agrobacterium clades using the ML, NJ, MP and ME methods were 98, 68, 49 and $74 \%$, respectively.

The data reported here are consistent with earlier reports that species allocated to Rhizobium, Allorhizobium, Agrobacterium and Sinorhizobium are found in two or three clades. One clade corresponds to Sinorhizobium: $S$. fredii (the types species), $S$. medicae, $S$. meliloti, S. sahelense, $S$. terangae and $S$. xinjiangense. The second cluster is more heterogeneous and may be considered to be represented by two subclades: 2a, including $R$. leguminosarum (the type 


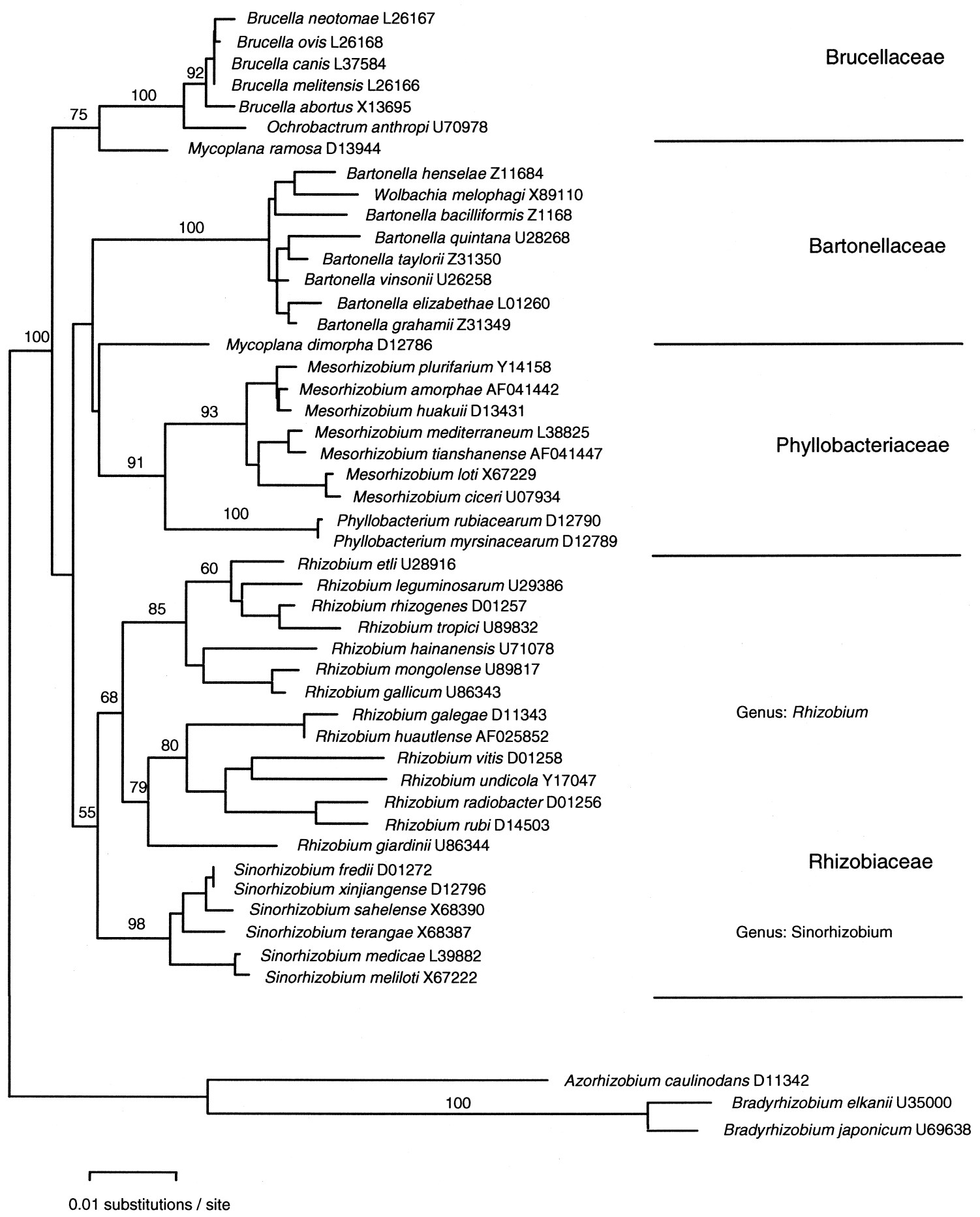

Fig. 2. Neighbour-joining tree expressing the relationships among the Rhizobiaceae and their relatives, based on $16 \mathrm{~S}$ rDNA sequences. Sites that include gaps in more than one sequence were excluded. Horizontal branch lengths are proportional to the estimated number of nucleotide substitutions and bootstrap probabilities (as percentages) are determined from 1000 resamplings.

species), R. etli, R. gallicum, R. giardinii, R. hainanense, $R$. mongolense, $R$. tropici and Agrobacterium rhizogenes; and 2b, including $R$. galegae, $R$. huautlense, Agrobacterium tumefaciens (the type species), Agrobacterium rubi, Agrobacterium vitis and Allorhizobium undicola. They have differences amounting to less than
$7 \%$ of the total sequence. The analyses reported here give no support for Allorhizobium as an outlying taxon/sequence. The extent of statistical support for individual branches and their relative positions depend on the form of phylogenetic analysis and the selection of sequences considered (Amarger et al., 1997; Chen et 
al., 1997; de Lajudie et al., 1994, 1998a, b; Jarvis et al., 1997; Nour et al., 1995; Rome et al., 1996; Sawada et al., 1993b; Tan et al., 1997; van Berkum et al., 1998; Wang et al., 1998; Willems \& Collins, 1993). Young \& Haukka (1996) and Eardly et al. (1996) note anomalies in sequence analyses attributable to recombination events between species, a conclusion supported but qualified by Wernegreen \& Riley (1999). As yet, the significance and implications of recombination on the inference of phylogenetic relationships are unclear (Martínez-Romero \& Caballero-Mellado, 1996).

Percentage differences based on pair-wise sequence comparisons were investigated (data not shown). Of rhizobial and agrobacterial sequences, $93 \%$ of pairwise comparisons gave values greater than $94 \%$. Between clusters, similarities ranged between $96.7 \%$ (huautlense/gallicum, huautlense/mongolense and gallicum/galegae) and 93.1\% (leguminosarum/ undicola). These data show a proportion of sequence pairs between clusters with percentage similarities as high as or higher than the percentage similarities of sequence pairs within clusters. This indicates relationships as close for species represented by sequence comparisons between clusters as those within clusters. Within cluster 1, percentage similarities ranged between 99.4 (fredii/xinjiangense and gallicum/mongolense), 97.5 (terangae/medicae and terangae/meliloti) and $96.2 \%$ (hainanense/tropici). Within cluster 2, percentage similarities ranged between 99.4 (galegae/huautlense) and 95.0\% (galegae/undicola). In the absence of supporting phenotypic data or DNA reassociation data, it is possible that some of these species are synonyms. Stackebrandt \& Goebel (1994) have noted the need to prove by other means the authenticity of species that share sequence similarities greater than $97 \%$, in order to guard against synonymy.

High pair-wise percentage similarities between sequences representing members of the Bartonellaceae and the Brucellaceae and the Rhizobiaceae represent an anomaly for any coherent classification. Brucella and Bartonella species are semi-fastidious mammalian pathogens, growth of which is favoured by serumbased media. Bartonella species are polymorphic rickettsia-like organisms. In phenotypic terms, they share few obvious similarities with the rhizobia. Sequences representing these genera have relatively high pair-wise sequence similarity values with the rhizobia, usually exceeding $93 \%$. Notably, several Brucella and Sinorhizobium species have similarity values of $96 \%$. Mycoplana sequences have similarity values with Sinorhizobium of 96-97\%. Rather than accepting such data uncritically as indicating close phylogenetic relationships, it is suggested that the limit of sensitivity for accurate phylogenetic inferences for these taxa using $16 \mathrm{~S}$ rDNA sequence alone may have been reached. The justifications for classification for these genera need alternative supporting sequences and more refined methods of analysis than are routinely available at present. Sneath (1989) noted the problem of establishing phylogenetic relationships of closely related taxa at the family level and below using $16 \mathrm{~S}$ rDNA sequence data. Although algorithmic methods (Swofford et al., 1996) provide support for branches of some closely related taxa, as yet there is no method universally applicable to all taxa.

Comparisons based on restriction analyses of $23 \mathrm{~S}$ rDNA indicated that strains from Rhizobium, Agrobacterium and Sinorhizobium have similar fragmentation patterns (Selenska-Pobell \& EvguenievaHackenberg, 1995). Terefework et al. (1998) and de Lajudie et al. (1998b) provide data showing that pathogenic and nodulating bacteria belonging to the genera Agrobacterium, Rhizobium and Sinorhizobium are interspersed on sub-branches of $16 \mathrm{~S}$ or $23 \mathrm{~S}$ rDNA phylogenetic trees.

\section{Anomalous sequences}

The family Rhizobiaceae also contains, as outliers to the rhizobial species, strains named Blastobacter spp. (Amarger et al., 1997; de Lajudie et al., 1998b; Young \& Haukka, 1996) that do not have symbiotic or pathogenic characteristics. Other strains of Blastobacter spp. are to be found in the families Methylobacteriaceae (four strains), Bradyrhizobiaceae and Sphingomonadaceae (one strain each). The strains of Blastobacter aggregatus ATCC 43293 and Blastobacter capsulatus ATCC 43294 in the Rhizobiaceae are therefore perhaps incorrectly named or sequenced. Sequences such as Mycoplana dimorpha D12786 also need re-examination.

\section{Generic definitions}

There are no formal criteria for the definition of bacterial genera, but the suggested minimal standards for the description of new genera and species of rootand stem-nodulating bacteria (Graham et al., 1991) can be considered as a reference and the definition of species proposed by Wayne et al. (1987) for producing phylogenetic classification is also illustrative. Wayne et al. (1987) proposed a formal species definition based on genomic data, but emphasized the need for phenotypic support. Since then, the significance of this emphasis has become clear (Goodfellow \& O'Donnell, 1993; Goodfellow et al., 1997). Genomic species, demonstrated by DNA-DNA reassociation data, are now accepted if circumscribed by phenotypic descriptions (using a selection of methods such as SDSPAGE of proteins, fatty acid profiles, multilocus enzyme electrophoresis, nutritional, biochemical and morphological characters etc.) that distinguish them from other species. They are not recognized on the basis of genomic data alone (Ursing et al., 1995). In a similar way, genera may be indicated according to a phylogenetic principle using sequence data, but such genera, as taxa, also need to be differentiated in unique phenotypic terms if they are to satisfy any systematics 
function other than understanding the historical relationships of the populations (Mayr, 1998). An important contribution to the discussion of the characterization of genera was provided by Murray et al. (1990), who noted the need for clarity of circumscription based on phenotypic properties at the level of genera, the impracticability of defining genera solely on the basis of phylogenetic data and the priority of phenotypic characterization over phylogenetic inference. As noted for Allorhizobium, there is no rational basis for making generic determinations unless there is phenotypic support for these taxa. Furthermore, proposed minimal standards for Agrobacterium and Rhizobium require that generic as well as species names should be based on both phenotypic and phylogenetic data (Graham et al., 1991).

Multiple character analysis towards a phenetic (Goodfellow \& O’Donnell, 1993) and polyphasic classification (sensu Vandamme et al., 1996) aims to produce coherent taxa with relevant circumscriptions (Young et al., 1992). A consideration of electrophoretic protein patterns and numerical analysis of nutritional and biochemical tests (de Lajudie et al., 1994) give a discrimination of species that is inconsistent with their segregation into Agrobacterium, Rhizobium and Sinorhizobium. Recently, de Lajudie et al. (1998b) reported comparative studies of Agrobacterium, Allorhizobium, Mesorhizobium, Rhizobium and Sinorhizobium using protein patterns, ITS regions of $16 \mathrm{~S}-23 \mathrm{~S}$ rDNA, 16S rDNA and carbon-source utilization. None of these methods supported the discrimination of the species into existing generic groupings. Furthermore, morphological and biochemical characters of species give no support for discrimination of these genera (Table 1). There are no phenotypic single or multiple characteristics reported in the generic circumscriptions of Agrobacterium, Allorhizobium, Rhizobium and Sinorhizobium by which these taxa, as genera, can be differentiated. Analysis of fatty acid profiles showed that Agrobacterium, Rhizobium and Sinorhizobium were closely related (Jarvis et al., 1996). 16S rDNA sequence data clearly show that Agrobacterium species (Willems \& Collins, 1993) are closely allied with Rhizobium species such as $R$. galegae (Lindström, 1989) and the recently described $R$. huautlense (Wang et. al., 1998) and Allorhizobium undicola (de Lajudie et al., 1998b). Agrobacterium rhizogenes is in a clade with the majority of Rhizobium species. The notable unifying character of members of the genera Agrobacterium and Rhizobium is their capacity to exchange and operate the large Sym and Ti plasmids (Abe et al., 1998; Hooykaas et al., 1977; Martínez et al., 1987). Agrobacterium can therefore be considered to be a polyphyletic genus that is an artificial amalgamation of plant-pathogenic species, similar in status to 'Phytomonas'.

\section{Proposed classification of Rhizobium}

The three named genera Agrobacterium, Allorhizobium and Rhizobium do not represent distinct phenotypic entities; they do not have unique phenotypic generic circumscriptions. Furthermore, evidence of their phylogenetic differentiation is not compelling and depends on the choice of algorithm and sequences included in the analysis. We therefore propose their amalgamation in the single genus named Rhizobium as the senior subjective synonym (Rule 38, International Code of Nomenclature of Bacteria; Lapage et al., 1992). The clades indicated, based only on branches from $16 \mathrm{~S}$ rDNA comparative analyses, suggest an evolutionary divergence that could be interpreted as the incipient formation of new subgenera. $R$. giardinii is an outlying species that is not stably associated with any cluster. Acceptance of the genus Allorhizobium based on the criteria on which it was proposed would provide a justification for large numbers of alternative classifications for which there are no distinguishing criteria. Allorhizobium is considered to be an artificial genus only justified at present on the basis of the anomalous state of Agrobacterium nomenclature. Allorhizobium undicola should therefore be renamed Rhizobium undicola.

The phenotypic descriptions of species previously named in Agrobacterium are reported by Holmes \& Roberts (1981), Kersters \& De Ley (1984), Ophel \& Kerr (1990), Sawada \& Ieki (1992a), de Lajudie et al. (1994) and Amarger et al. (1997). The phenotypic description of $R$. undicola is given by de Lajudie et al. (1998b).

Comparative analyses of $16 \mathrm{~S}$ rDNA sequence data indicate that Mesorhizobium may be more closely related to Phyllobacterium than to Rhizobium and Sinorhizobium, and their differing phenotypic generic characters (a slower growth rate, suggesting underlying metabolic differences, and distinct fatty acid profile; Jarvis et al., 1996) are considered to justify their separation from other members of Rhizobium.

Sinorhizobium species could be considered as a subgeneric clade within the revised genus Rhizobium as proposed here. The absence of phenotypic support for separation of this genus from Rhizobium is justification for a proposal of synonymy. However, personal communications from colleagues suggest that phenotypic support for the genus may be pending and consideration needs to be given to possible publications before further revisions are made. In the meantime, this genus is retained as a separate taxon pending future consideration of its status.

\section{Note on the nomenclature of Agrobacterium and pathogenic species}

Bradbury (1986), Holmes \& Roberts (1981), Holmes (1988) and Young et al. (1992) have supported the use of the names Agrobacterium tumefaciens and Agrobacterium rhizogenes, in accord with natural classification, recognizing pathogenicity of strains according 
Table 1. Characteristics of Rhizobium (including Agrobacterium and Allorhizobium) and Sinorhizobium species

Taxa are indicated as: 1, Rhizobium leguminosarum $; 2, R$ etli $; 3, R$ galegae $; 4, R$ gallicum; $5, R$ giardinii $; 6, R$. hainanense; $7, R$, huautlense; $8, R$. mongolense; $9, R$. radiobacter; 10, R. rhizogenes; 11, R. rubi; 12, R. tropici; 13, R. undicola; 14, R. vitis; 15 , Sinorhizobium fredii; $16, S$. medicae; $17, S$. meliloti; $18, S$. sahelense; 19, S. terangae; and 20, S. xinjiangense. Data were taken from Graham \& Parker (1964), Jordan (1984), Kersters \& De Ley (1984), Kerr (1992) and the original species descriptions. +, More than $90 \%$ of strains expected to give a positive reaction; $\mathrm{d}, 10-90 \%$ of strains expected to give a positive reaction; - , fewer than $10 \%$ of strains expected to give a positive reaction; $(+)$ weak growth in $2 \% \mathrm{NaCl}$.

\begin{tabular}{|c|c|c|c|c|c|c|c|c|c|c|c|c|c|c|c|c|c|c|c|c|}
\hline \multirow[t]{2}{*}{ Character } & \multicolumn{14}{|c|}{ Rhizobium } & \multicolumn{6}{|c|}{ Sinorhizobium } \\
\hline & 1 & 2 & 3 & 4 & 5 & 6 & 7 & 8 & 9 & 10 & 11 & 12 & 13 & 14 & 15 & 16 & 17 & 18 & 19 & 20 \\
\hline Polar flagella & & & $1-2$ & & & 1 & & & & & & & & & & & & $\geqslant 1$ & $\geqslant 1$ & \\
\hline $\begin{array}{l}\text { Peritrichous (or one subpolar) } \\
\text { flagella }\end{array}$ & $2-6$ & & $1-2$ & & & & & 1 & $1-4$ & $1-4$ & $1-4$ & Yes & Yes & $1-4$ & $1-3$ & & $2-6$ & $\geqslant 1$ & $\geqslant 1$ & $1-3$ \\
\hline 3-Ketolactose produced & - & $\_a *$ & - & - & - & - & & & + & - & - & - & - & - & - & & - & - & - & \\
\hline Growth factors required: & + & - & + & & & & & & - & + & + & $-^{a}$ & - & + & & & + & & & \\
\hline Biotin & $\mathrm{d}$ & - & & & & & & & - & + & + & $-^{a}$ & - & + & & & $\mathrm{d}$ & & & \\
\hline Pantothenate & + & - & + & & & & - & & - & & + & $-^{a}$ & - & & & - & - & & & \\
\hline Thiamin & $\mathrm{d}$ & - & - & & & & + & & - & & & $-^{a}$ & - & & & - & - & & & \\
\hline $\mathrm{pH}$ range for growth & $4-9$ & & $5-9 \cdot 5^{b}$ & $>4-8$ & $<4-8.5$ & $5-10$ & $5-9$ & $4-10$ & & $5-9$ & & $4-10$ & & & $5-10 \cdot 5$ & $5-10$ & $4 \cdot 5-9 \cdot 5$ & & & $5-10 \cdot 5$ \\
\hline \multicolumn{21}{|l|}{ Growth in/at: } \\
\hline $28^{\circ} \mathrm{C}$ & + & + & + & + & + & + & + & + & + & + & + & + & + & + & + & + & + & + & + & + \\
\hline $35^{\circ} \mathrm{C}$ & & + & + & & & + & + & & + & - & - & & & - & + & + & + & + & + & + \\
\hline $40^{\circ} \mathrm{C}$ & - & - & - & - & - & + & + & & & - & - & + & & - & - & $\mathrm{d}$ & $\mathrm{d}$ & + & + & \\
\hline $1 \% \mathrm{NaCl}$ & - & & $\mathrm{d}^{b}$ & - & $\mathrm{d}$ & + & + & - & + & & & - & & + & + & + & + & & & + \\
\hline $2 \% \mathrm{NaCl}$ & - & & - & - & - & + & - & - & + & - & - & - & & + & $\mathrm{d}$ & + & $\mathrm{d}$ & & & $(+)$ \\
\hline Luria-Bertani medium & - & - & - & - & - & + & - & & + & & & + & & & - & + & + & - & - & - \\
\hline $\begin{array}{l}\text { Oncogenicity to few or } \\
\text { many plant genera }\end{array}$ & - & - & - & - & - & - & - & & Many & Many & Few & - & - & Few & - & - & - & - & - & - \\
\hline $\begin{array}{l}\text { Symbiotic nodulating/ } \\
\text { nitrogen-fixing capacity }\end{array}$ & + & + & + & + & + & + & + & + & - & - & - & + & + & - & + & + & + & + & + & + \\
\hline
\end{tabular}

* Unpublished results (E. Martínez-Romero ${ }^{a}$ or E.-T. Wang ${ }^{b}$ ) obtained using the methods of Wang et al. (1998). 
to their 'tumorigenic', 'rhizogenic' and 'non-pathogenic' states. This use appears to pose problems of comprehension: the epithet tumefaciens is too closely associated with tumorigenicity to stand independently as a species name. Attempts to resolve the difficulty by recognizing Agrobacterium radiobacter in place of Agrobacterium tumefaciens (Kerr et al., 1978; Kersters \& De Ley, 1984; Sawada et al., 1993b) cannot be adopted because Agrobacterium tumefaciens was conserved as the type species (Judicial Commission, 1970). Bouzar (1994) sought clarification of the proposal of Sawada et al. (1993b) which, with the response of $\mathrm{H}$. Oyaizu and H. Sawada (Bouzar, 1994), the Judicial Commission of the ICSB deemed to have resolved the matter (L. G. Wayne, personal communication). The practical and usual solution to this nomenclatural confusion has been to use an artificial classification and irregular nomenclature, in which the species names Agrobacterium tumefaciens or Agrobacterium rhizogenes are applied to the pathogenic plasmid-borne states and the terms 'biotype' or 'biovar' are applied to the natural species groups. It is likely that this problem will persist for Agrobacterium nomenclature in the foreseeable future. Coincidentally, this problem is dissolved by the amalgamation of Agrobacterium and Rhizobium because the epithet radiobacter has chronological priority over tumefaciens and can be applied in the latter genus.

If the genus Agrobacterium is differentiated from Rhizobium in the future, the use of a natural classification that recognizes Agrobacterium species will probably require a radical change of nomenclature by application of the Code (Lapage et al., 1992). At least, the name Agrobacterium tumefaciens should be rejected (Rule 23a) as a nomen ambiguum; a name that has been used with different meanings and has thus become a source of error (Rule 56a). This would also involve the designation of a new type species. The obvious candidate is Agrobacterium radiobacter. For both these proposals, it would be necessary to make a Request for an Opinion to the Judicial Commission of the ICSB. A more radical option could involve the application of new names (and a new type species), extending the proposal of Kersters \& De Ley (1984).

Elsewhere, the application of pathovars in terms of the Standards for Naming Pathovars (Dye et al., 1980) has been proposed (Kerr et al., 1978; Kersters \& De Ley, 1984). However, the fact that most pathogenicity genes are carried on plasmids means that the pathogenic character of any strain is unstable. This lack of stability would make uncertain the application of pathovar names to particular strains, most notably to pathotype strains. For pathogenic strains in Rhizobium, therefore, this formal special purpose nomenclature (Dye et al., 1980) seems inappropriate. Species comprising pathogenic or non-pathogenic strains can be reported as tumorigenic (as a 'Ti strain' or ' $\mathrm{Ti}$ '), as a rhizogenic 'Ri strain' or ' $\mathrm{Ri}$ ', or as non-pathogenic strains of the species, where relevant.
Emended description of the genus Rhizobium Frank $1889,338^{\mathrm{AL}}$ (Agrobacterium Conn 1942, 359 ${ }^{\mathrm{AL}}$; Allorhizobium de Lajudie, Laurent-Fulele, Willems, Torck, Coopman, Collins, Kersters, Dreyfus and Gillis 1998b, 1288 ${ }^{\mathrm{VP}}$ )

Rhizobium (Rhi.zo'bi.um. Gr. n. rhiza a root; Gr. n. bios life; M. L. neut. n. Rhizobium that which lives in a root).

Cells are rods, $0 \cdot 5-1 \cdot 0 \times 1 \cdot 2-3 \cdot 0 \mu \mathrm{m}$. Non-sporeforming. Gram-negative. Motile by one to six flagella. Insertion usually peritrichous or peritrichous/ subpolar. Fimbriae have been described on some strains. Aerobic, possessing a respiratory type of metabolism with oxygen as the terminal electron acceptor. Optimum temperature for growth is 25$30{ }^{\circ} \mathrm{C}$; some species can grow at temperatures above $40{ }^{\circ} \mathrm{C}$. Optimum $\mathrm{pH}, 6-7$; range, $\mathrm{pH} 4-10$. Generation times of Rhizobium strains are $1.5-3.0 \mathrm{~h}$. Colonies are usually white or beige, circular, convex, semi-translucent or opaque, raised and mucilaginous, usually $2-4 \mathrm{~mm}$ in diameter within $3-5 \mathrm{~d}$ on yeast/ mannitol/mineral salts agar(YMA). Growth on carbohydrate media is usually accompanied by copious amounts of extracellular polysaccharide slime. Pronounced turbidity develops after 2 or $3 \mathrm{~d}$ in aerated or agitated broth. Chemoorganotrophic, utilizing a wide range of carbohydrates and salts of organic acids as sole carbon sources, without gas formation. Cellulose and starch are not utilized. Produce an acidic reaction in mineral salts medium containing mannitol or other carbohydrates. Ammonium salts, nitrate, nitrite and most amino acids can serve as nitrogen sources. Strains of some species will grow in a simple mineral salts medium with vitamin-free casein hydrolysate as the sole source of both carbon and nitrogen, but strains of many species require one or more growth factors such as biotin, pantothenate or nicotinic acid. Peptone is poorly utilized. Casein, starch, chitin and agar are not hydrolysed. Members of Rhizobium are distinguished from those in the related genera, Mesorhizobium and Phyllobacterium, by differences in growth rate, fatty acid profiles and 16S rDNA sequence. Closely related in terms of $16 \mathrm{~S}$ rDNA sequence similarity, all known Rhizobium species include strains that induce hypertrophisms in plants. Hypertrophisms in most species are root nodules either with or without symbiotic nitrogen fixation, while in other species they occur as unregulated oncogenic (tumorigenic or rhizogenic) growths. Some cells of symbiotic bacterial species enter root hair cells of leguminous plants (family Leguminosae) via invagination or by wounds ('crack entry') and elicit the production of root nodules, wherein the bacteria engage as intracellular symbionts, usually fixing nitrogen. Many well-defined nodulation (nod) and nitrogen fixation (nif) genes are clustered on large or megaplasmids (pSyms). Plant-host specificity is usually for a few legume genera but may, in some strains, extend to many legume genera and is largely determined by the chemical structure of lipochito- 
oligosaccharide Nod factors produced (Dénarié et al., 1992, 1996). These highly specific 'cell-walllike' molecules induce nodule organogenesis in the absence of bacteria. Strains of plant-pathogenic Rhizobium (previously Agrobacterium) species invade the crown, roots and stems of many dicotyledonous and some gymnospermous plants via wounds. Selfproliferating tumours are induced by the genetic transfer of a small DNA region carried on large tumour-inducing $\mathrm{Ti}$ or hairy-root-inducing Ri plasmids into the host plant genome. Plasmid transfer between species results in the expression and stable inheritance of the particular plant-interactive properties of the plasmid-donor species.

The $\mathrm{G}+\mathrm{C}$ content of the DNA is $57-66 \mathrm{~mol} \%\left(T_{\mathrm{m}}\right)$. The type species is Rhizobium leguminosarum (Frank 1879) Frank $1889,338^{\mathrm{AL}}$.

\section{Emended description of Rhizobium radiobacter (Beijerinck and van Delden 1902) comb. nov. (Agrobacterium radiobacter (Beijerinck and van Delden 1902) Conn 1942, 359 ${ }^{\mathrm{AL}}$; Agrobacterium tumefaciens (Smith and Townsend 1907, 672) Conn 1942, 359 ${ }^{\mathrm{AL}}$ )}

The phenotypic description of Rhizobium radiobacter is reported by Holmes \& Roberts (1981), Kersters \& De Ley (1984), Sawada \& Ieki (1992a), de Lajudie et al. (1994) and Amarger et al. (1997).

Ti or Ri plasmids determine the pathogenic status of strains. The species comprises pathogenic or nonpathogenic strains, both of which can be reported as tumorigenic; as a 'Ti strain' or ' $\mathrm{Ti}$ ', as a rhizogenic 'Ri strain' or 'Ri' or as non-pathogenic strains of the species where relevant. Pathogenic strains have a wide and perhaps complex host range.

The epithet tumefaciens was conserved as the type species for Agrobacterium. The epithet radiobacter takes precedence over tumefaciens as the senior subjective synonym in Rhizobium.

The type strain is ATCC $19358^{\mathrm{T}}\left(=\mathrm{DSM} 30147^{\mathrm{T}}\right.$; = IFO $13532^{\mathrm{T}} ;=\operatorname{ICMP} 5785^{\mathrm{T}} ;=\operatorname{NCIB} 9042^{\mathrm{T}} ;=$ NCPPB $3001^{\mathrm{T}}$ ).

Emended description of Rhizobium rhizogenes (Riker, Banfield, Wright, Keitt and Sagen 1930) comb. nov. (Agrobacterium rhizogenes (Riker, Banfield, Wright, Keitt and Sagen 1930) Conn 1942, 359 ${ }^{\mathrm{AL}}$ )

The phenotypic description of Rhizobium rhizogenes is reported by Holmes \& Roberts (1981), Kersters \& De Ley (1984), Sawada \& Ieki (1992a), de Lajudie et al. (1994) and Amarger et al. (1997).

Ti or Ri plasmids determine the pathogenic status of strains. The species comprises pathogenic or nonpathogenic strains that can be reported as tumorigenic, as a 'Ti strain' or ' $\mathrm{Ti}$ ', as a rhizogenic ' $\mathrm{Ri}$ strain' or 'Ri' or as non-pathogenic strains of the species where relevant. Pathogenic strains have a wide and perhaps complex host range.

The type strain is ATCC $11325^{\mathrm{T}}\left(=\mathrm{DSM} 30148^{\mathrm{T}}\right.$; = ICMP $5794^{\mathrm{T}}$; = IFO $13257^{\mathrm{T}}$ ).

Emended description of Rhizobium rubi (Hildebrand 1940) comb. nov. (Agrobacterium rubi (Hildebrand 1940) Starr and Weiss $1943,316^{\text {AL }}$ )

The phenotypic description of Rhizobium rubi is reported by Holmes \& Roberts (1981), Kersters \& De Ley (1984), Sawada \& Ieki (1992a), de Lajudie et al. (1994) and Amarger et al. (1997).

The species comprises pathogenic and non-pathogenic strains that can be reported as tumorigenic, as a $\mathrm{Ti}$ strain or Ti, or as non-pathogenic strains of the species where relevant. Isolated from above-ground cane galls on Rubus spp. (black raspberry, boysenberry). The host range is not limited to Rubus spp. (Anderson \& Moore, 1979).

The type strain is ATCC $13335^{\mathrm{T}}\left(=\mathrm{CFBP} 1317^{\mathrm{T}}\right.$; = ICMP $6428^{\mathrm{T}}$; = IFO $13261^{\mathrm{T}}$; = LMG $156^{\mathrm{T}}$; $=$ NCPPB $1854^{\mathrm{T}}$ ).

Emended description of Rhizobium undicola (de Lajudie, Laurent-Fulele, Willems, Torck, Coopman, Collins, Kersters, Dreyfus and Gillis 1998) comb. nov. (Allorhizobium undicola de Lajudie et al. 1998, $\left.1288^{\mathrm{VP}}\right)$

The phenotypic description of Rhizobium undicola is reported by de Lajudie et al. (1998b).

Members of this species fix nitrogen when in a natural symbiotic association with Neptunia natans. They also form symbiotic associations with Acacia spp., Faidherbia spp. and Lotus arabicus, but not with Medicago spp. or Sesbania spp. in artificial inoculation.

The type strain is $\mathrm{ORS}_{992^{\mathrm{T}}}\left(=\mathrm{LMG} 11875^{\mathrm{T}}\right)$.

\section{Emended description of Rhizobium vitis (Ophel and Kerr 1990) comb. nov. (Agrobacterium vitis Ophel and Kerr 1990, 240 ${ }^{\mathrm{VP}}$ )}

The phenotypic description of Rhizobium vitis is reported by Ophel \& Kerr (1990).

Ti plasmids determine the pathogenic status of strains. The species comprises pathogenic or non-pathogenic strains that can be reported as tumorigenic (Ti strain) or non-pathogenic strains of the species where relevant. Strains are generally isolated from Vitis spp. (grape), but they have occasionally been isolated from other dicotyledonous plant species.

The type strain is ATCC $49767^{\mathrm{T}}\left(=\operatorname{ICMP} 10752^{\mathrm{T}}\right.$; $=$ NCPPB $3554^{\mathrm{T}}$ ). 


\section{ACKNOWLEDGEMENTS}

D.-C. Park assisted in preparing figures. Dr S. R. Pennycook and Dr P. K. Buchanan critically reviewed the manuscript. This study was supported in part by the New Zealand Foundation for Research Science and Technology under contract no. CO9309 (J.M.Y.).

\section{REFERENCES}

Abe, M., Kawamura, R., Higashi, S., Mori, S., Shibata, M. \& Uchiumi, T. (1998). Transfer of the symbiotic plasmid from Rhizobium leguminosarum biovar trifolii to Agrobacterium tumefaciens. J Gen Appl Microbiol 44, 65-74.

Adachi, J. \& Hasegawa, M. (1996). MOLPHY. Programs for Molecular Phylogenetics, version 2.3. Institute of Statistical Mathematics, Tokyo, Japan.

Amarger, N., Macheret, V. \& Laguerre, G. (1997). Rhizobium gallicum sp. nov. and Rhizobium giardinii sp. nov., from Phaseolus vulgaris nodules. Int J Syst Bacteriol 47, 996-1006.

Anderson, A. R. \& Moore, L. W. (1979). Host specificity in the genus Agrobacterium. Phytopathology 69, 153-158.

Beijerinck, M. W. \& van Delden, A. (1902). Ueber die Assimilation des freien Stickstoffs durch Bakterien. Zentbl Bakt Parasitenk Infekt Abt II 9, 3-43.

van Berkum, P., Beyene, D., Bao, G., Campbell, T. A. \& Eardly، B. D. (1998). Rhizobium mongolense sp. nov. is one of three rhizobial genotypes identified which nodulate and form nitrogen-fixing symbioses with Medicago ruthenica [(L.) Ledebour]. Int J Syst Bacteriol 48, 13-22.

Bouzar, H. (1994). Request for a judicial opinion concerning the type species of Agrobacterium. Int J Syst Bacteriol 44, 373-374.

Bouzar, H., Ouadah, D., Krimi, Z., Jones, J. B., Trovato, M., Petit, A. \& Dessaux, Y. (1993). Correlative association between resident plasmids and the host chromosome in a diverse Agrobacterium soil population. Appl Environ Microbiol 59, 1310-1317.

Bradbury, J. F. (1986). Guide to Plant Pathogenic Bacteria. Kew. London: CAB International Mycological Institute.

Chen, W. X., Yan, G. H. \& Li, J. L. (1988). Numerical taxonomic study of fast-growing soybean rhizobia and a proposal that Rhizobium fredii be assigned to Sinorhizobium gen. nov. Int $J$ Syst Bacteriol 38, 392-397.

Chen, W. X., Li, G. S., Qi, Y. L., Wang, E. T., Yuan, H. L. \& Li, J. L. (1991). Rhizobium huakuii sp. nov. isolated from the root nodules of Astragalus sinicus. Int J Syst Bacteriol 41, 275-280.

Chen, W., Wang, E., Wang, S., Li, Y., Chen, X. \& Li, Y. (1995). Characteristics of Rhizobium tianshanense sp. nov., a moderately and slowly growing root nodule bacterium isolated from an arid saline environment in Xinjiang, People's Republic of China. Int J Syst Bacteriol 45, 153-159.

Chen, W.-X., Tan, Z.-Y., Gao, J.-L., Li, Y. \& Wang, E.-T. (1997). Rhizobium hainanense sp. nov., isolated from tropical legumes, Int J Syst Bacteriol 47, 870-873.

Conn, H. J. (1942). Validity of the genus Alcaligenes. J Bacteriol 44, 353-360.

De Ley, J. (1968). DNA base composition and hybridization in the taxonomy of the phytopathogenic bacteria. Annu Rev Phytopathol 6, 63-90.

De Ley, J. (1972). Agrobacterium: intrageneric relationships and evolution. In Plant Pathogenic Bacteria 1971, pp. 251-259. Proceedings of the 3rd International Conference on Plant
Pathology and Bacteriology, 14-21 April 1971. Edited by H. P. Maas-Geesteranus. Wageningen: Centre for Agricultural Publishing and Documentation (Pudoc).

De Ley, J. (1974). Phylogeny of the prokaryotes. Taxon 23, 291-300.

De Ley, J., Tijtgat, R., De Smedt, J. \& Michiels, M. (1973). Thermal stability of DNA:DNA hybrids within the genus Agrobacterium. J Gen Microbiol 78, 241-252.

Dénarié, J., Debellé, F. \& Rosenberg, C. (1992). Signaling and host range variation in nodulation. Annu Rev Microbiol 46, 497-531.

Dénarié, J., Debellé, F. \& Promé, J. C. (1996). Rhizobium lipochitooligosaccharide nodulation factors: signalling molecules mediating recognition and morphogenesis. Annu Rev Biochem 65, 503-535.

Dreyfus, B., Garcia, J. L. \& Gillis, M. (1988). Characterization of Azorhizobium caulinodans gen. nov., sp. nov., a stem-nodulating nitrogen-fixing bacterium isolated from Sesbania rostrata. Int $J$ Syst Bacteriol 38, 89-98.

Dye, D. W., Bradbury, J. F., Goto, M., Hayward, A. C., Lelliott, R. A. \& Schroth, M. N. (1980). International standards for naming pathovars of phytopathogenic bacteria and list of pathovar names and pathotype strains. Rev Plant Pathol 59, 153-168.

Eardly, B. D., Wang, F.-S. \& van Berkum, P. (1996). Corresponding 16S rRNA gene segments in Rhizobiaceae and Aeromonas yield discordant phylogenies. Plant Soil 186, 69-74.

Felsenstein, J. (1978). Cases in which parsimony and compatibility methods will be positively misleading. Syst Zool 27, 401-410.

Felsenstein, J. (1981). Evolutionary trees from DNA sequences: a maximum likelihood approach. J Mol Evol 17, 368-376.

Felsenstein, J. (1985). Confidence limits on phylogenies: an approach using the bootstrap. Evolution 39, 783-791.

Frank, B. (1879). Ueber die Parasiten in den Wurzelanschwillingen der Papilionaceen. Bot Ztg 37, 376-387, 394-399.

Frank, B. (1889). Ueber die Pilzsymbiose der Leguminosen. Ber Dtsch Bot Ges 7, 332-346.

Goodfellow, M. \& O’Donnell, A. G. (1993). Roots of bacterial systematics. In Handbook of New Bacterial Systematics, pp. 3-54. Edited by M. Goodfellow \& A. G. O'Donnell. London: Academic Press.

Goodfellow, M., Manfio, G. P. \& Chun, J. (1997). Towards a practical species concept for cultivable bacteria. In Species: the Units of Biodiversity, pp. 25-59. Edited by M. F. Claridge, H. A. Dawah \& M. R. Wilson. London: Chapman Hall.

Graham, P. H. (1964). The application of computer techniques to the taxonomy of the root-nodule bacteria of legumes. J Gen Microbiol 35, 511-517.

Graham, P. H. (1976). Identification and classification of root nodule bacteria. In Symbiotic Nitrogen Fixation in Plants, pp. 99-112. International Biological Programme no. 7. Edited by P. S. Nutman. London: Cambridge University Press.

Graham, P. H. \& Parker, C. A. (1964). Diagnostic features in the characterization of the root-nodule bacteria of legumes. Plant Soil 20, 383-396.

Graham, P. H., Sadowsky, M. J., Keyser, H. H. and 8 other authors (1991). Proposed minimal standards for the description of new genera and species of root- and stem-nodulating bacteria. Int $J$ Syst Bacteriol 41, 582-587. 
Hasegawa, M. \& Kishino, H. (1994). Accuracies of the simple methods for estimating the bootstrap probability of a maximum likelihood tree. Mol Biol Evol 11, 142-145.

Hasegawa, M., Kishino, H. \& Yano, T. (1985). Dating of the human-ape splitting by a molecular clock of mitochondrial DNA. J Mol Evol 22, 160-174.

Hasegawa, M., Kishino, H. \& Saitou, N. (1991). On the maximum likelihood method in molecular phylogenetics. J Mol Evol 32, 443-445.

Heberlein, G. T., De Ley, J. \& Tijtgat, R. (1967). Deoxyribonucleic acid homology and taxonomy of Agrobacterium, Rhizobium, and Chromobacterium. J Bacteriol 94, 116-124.

Hildebrand, E. M. (1940). Cane gall of brambles caused by Phytomonas rubi n. sp. J Agric Res 61, 685-696.

Holmes, B. (1988). Taxonomy of Agrobacterium. Acta Hortic 225, 47-52.

Holmes, B. \& Roberts, P. (1981). The classification, identification and nomenclature of agrobacteria. J Appl Bacteriol 50, 443-467.

Hooykaas, P. J. J., Klapwijk, P. M., Nuti, M. P., Schilperoort, R. A. \& Rörsch, A. (1977). Transfer of the Agrobacterium tumefaciens TI plasmid to avirulent agrobacteria and to Rhizobium ex planta. J Gen Microbiol 98, 477-484.

Jarvis, B. D. W., Gillis, M. \& De Ley, J. (1986). Intra- and intergeneric similarities between the ribosomal ribonucleic acid cistrons of Rhizobium and Bradyrhizobium species and some related bacteria. Int J Syst Bacteriol 36, 129-138.

Jarvis, B. D. W., Ward, L. J. H. \& Slade, E. A. (1989). Expression by soil bacteria of nodulation genes from Rhizobium leguminosarum. Appl Environ Microbiol 55, 1426-1434.

Jarvis, B. D. W., Sivakumaran, S., Tighe, S. W. \& Gillis, M. (1996). Identification of Agrobacterium and Rhizobium species based on cellular fatty acid composition. Plant Soil 184, 143-158.

Jarvis, B. D. W., van Berkum, P., Chen, W. X., Nour, S. M., Fernandez, M. P., Cleyet-Marel, J. C. \& Gillis, M. (1997). Transfer of Rhizobium loti, Rhizobium huakuii, Rhizobium ciceri, Rhizobium mediterraneum, and Rhizobium tianshansense to Mesorhizobium gen. nov. Int J Syst Bacteriol 47, 895-898.

Jordan, D. C. (1982). Transfer of Rhizobium japonicum Buchanan 1980 to Bradyrhizobium gen. nov., a genus of slow-growing, root nodule bacteria from leguminous plants. Int $J$ Syst Bacteriol 32, 136-139.

Jordan, D. C. (1984). Genus I. Rhizobium Frank 1889, 338 ${ }^{\mathrm{AL}}$. In Bergey's Manual of Systematic Bacteriology, vol. 1, pp. 235-242. Edited by N. R. Krieg \& J. G. Holt. Baltimore: Williams \& Wilkins.

Judicial Commission (1970). Opinion 33. Conservation of the generic name Agrobacterium Conn 1942. Int J Syst Bacteriol 20, 10 .

Keane, P. J., Kerr, A. \& New, R. B. (1970). Crown gall of stone fruit. II. Identification and nomenclature of Agrobacterium isolates. Aust J Biol Sci 23, 585-595.

Kerr, A. (1992). The genus Agrobacterium. In The Prokaryotes, 2nd edn, pp. 2214-2235. Edited by A. Balows, H. G. Trüper, M. Dworkin, W. Harder \& K.-H. Schleifer. Heidelberg: Springer.

Kerr, A. \& Panagopoulos, C. G. (1977). Biotypes of Agrobacterium radiobacter var. tumefaciens and their biological control. Phytopathol Z 90, 172-179.

Kerr, A., Young, J. M. \& Panagopoulos, C. G. (1978). Genus II. Agrobacterium Conn 1942. NZ J Agric Res 21, 155-156.
Kersters, K. \& De Ley, J. (1975). Identification and grouping of bacteria by numerical analysis of their electrophoretic protein patterns. J Gen Microbiol 87, 333-342.

Kersters, K. \& De Ley, J. (1984). Genus III. Agrobacterium Conn 1942, 359 ${ }^{\mathrm{AL}}$. In Bergey's Manual of Systematic Bacteriology, vol. 1, pp. 244-254. Edited by N. R. Krieg \& J. G. Holt. Baltimore: Williams \& Wilkins.

Kersters, K., De Ley, J., Sneath, P. H. A. \& Sackin, M. (1973). Numerical taxonomic analysis of Agrobacterium. $J$ Gen Microbiol 78, 227-239.

Kimura, M. (1980). A simple method for estimating evolutionary rates of base substitutions through comparative studies of nucleotide sequences. J Mol Evol 16, 111-120.

Knösel, D. H. (1984). Genus IV. Phyllobacterium (ex Knösel 1962) nom. rev. (Phyllobacterium Knösel 1962, 96). In Bergey's Manual of Systematic Bacteriology, vol. 1, pp. 254-256. Edited by N. R. Krieg \& J. G. Holt. Baltimore: Williams \& Wilkins.

Kuykendall, L. D., Saxena, B., Devine, T. E. \& Udell, S. E. (1993). Bradyrhizobium elkanii sp. nov. In Validation of the Publication of New Names and New Combinations Previously Effectively Published Outside the IJSB. List no. 45. Int J Syst Bacteriol 43, 398-399.

Laguerre, G., Bardin, M. \& Amarger, N. (1993). Isolation from soil of symbiotic and nonsymbiotic Rhizobium leguminosarum by DNA hybridization. Can J Microbiol 39, 1142-1149.

Laguerre, G., van Berkum, P., Amarger, N. \& Prévost, D. (1997). Genetic diversity of rhizobial symbionts isolated from legume species within the genera Astragalus, Oxytropis, and Onobrychis. Appl Environ Microbiol 63, 4748-4758.

de Lajudie, P., Willems, A., Pot, B. and 7 other authors (1994). Polyphasic taxonomy of rhizobia: emendation of the genus Sinorhizobium and description of Sinorhizobium meliloti comb. nov., Sinorhizobium saheli sp. nov., and Sinorhizobium teranga sp. nov. Int $J$ Syst Bacteriol 44, 715-733.

de Lajudie, P., Willems, A., Nick, G. and 9 other authors (1998a). Characterization of tree rhizobia and description of Mesorhizobium plurifarium sp. nov. Int J Syst Bacteriol 48, 369-382.

de Lajudie, P., Laurent-Fulele, E., Willems, A., Torck, U., Coopman, R., Collins, M. D., Kersters, K., Dreyfus, D. \& Gillis, M. (1998b). Description of Allorhizobium undicola gen. nov., sp. nov. for nitrogen-fixing bacteria efficiently nodulating Neptunia natans in Senegal. Int J Syst Bacteriol 48, 1277-1290.

Lapage, S. P., Sneath, P. H. A., Lessel, E. F., Skerman, V. B. D., Seeliger, H. P. R. \& Clark, W. A. (editors) (1992). International Code of Nomenclature of Bacteria (1990 Revision). Bacteriological Code. Washington, DC: American Society for Microbiology.

Lindström, K. (1989). Rhizobium galegae, a new species of legume root nodule bacteria. Int $J$ Syst Bacteriol 39, 365-367.

Martínez, E., Palacios, R. \& Sánchez, F. (1987). Nitrogen-fixing nodules induced by Agrobacterium tumefaciens harboring Rhizobium phaseoli plasmids. J Bacteriol 169, 2828-2834.

Martínez-Romero, E. \& Caballero-Mellado, J. (1996). Rhizobium phylogenies and bacterial genetic diversity. Crit Rev Plant Sci 15, 113-140.

Martínez-Romero, E. \& Palacios, R. (1990). The Rhizobium genome. Crit Rev Plant Sci 9, 59-93.

Martínez-Romero, E., Segovia, L., Mercante, F. M., Franco, A. A., Graham, P. \& Pardo, M. A. (1991). Rhizobium tropici, a novel species nodulating Phaseolus vulgaris L. beans and Leucaena $\mathrm{sp}$. trees. Int J Syst Bacteriol 41, 417-426. 
Mayr, E. (1998). Two empires or three? Proc Natl Acad Sci U S A 95, 9720-9723.

Murray, R. G. E., Brenner, D. J., Colwell, R. R., De Vos, P., Goodfellow, M., Grimont, P. A. D., Pfenning, N., Stackebrandt, E. \& Zavarzin, G. A. (1990). Report of the ad hoc committee on approaches to taxonomy within the Proteobacteria. Int J Syst Bacteriol 40, 213-215.

Nick, G., de Lajudie, P., Eardly, B. D., Suomalainen, S., Paulin, L., Zhang, X., Gillis, M. \& Lindström, K. (1999). Sinorhizobium arboris sp. nov. and Sinorhizobium kostiense sp. nov., isolated from leguminous trees in Sudan and Kenya. Int J Syst Bacteriol 49, 1359-1368.

Nour, S. M., Fernandez, M. P., Normand, P. \& Cleyet-Marel, J.-C. (1994). Rhizobium ciceri sp. nov., consisting of strains that nodulate chickpeas (Cicer arietinum L.). Int J Syst Bacteriol 44, 511-522.

Nour, S. M., Cleyet-Marel, J.-C., Normand, P. \& Fernandez, M. P. (1995). Genomic heterogeneity of strains nodulating chickpeas (Cicer arietinum L.) and description of Rhizobium mediterraneum sp. nov. Int J Syst Bacteriol 45, 640-648.

Ophel, K. \& Kerr, A. (1990). Agrobacterium vitis sp. nov. for strains of Agrobacterium biovar 3 from grapevines. Int J Syst Bacteriol 40, 236-241.

Panagopoulos, C. G., Psallidas, P. G. \& Alivizatos, A. S. (1978). Studies on biotype 3 of Agrobacterium radiobacter var. tumefaciens. In Plant Pathogenic Bacteria, vol. 1, pp. 221-228. Proceedings of the 4th International Conference on Plant Pathology and Bacteriology, Angers 1978. Edited by Station de Pathologie Végétale et Phytobactériologie. Angers, France: INRA.

Riker, A. J., Banfield, W. M., Wright, W. H., Keitt, G. W. \& Sagen, H. E. (1939). Studies on infectious hairy root of nursery trees of apples. J Agric Res 41, 507-540.

Rome, S., Fernandez, M. P., Brunel, B., Normand, P. \& CleyetMarel, J.-C. (1996). Sinorhizobium medicae sp. nov., isolated from annual Medicago spp. Int J Syst Bacteriol 46, 972-980.

Rzhetsky, A. \& Nei, M. (1992). A simple method for estimating and testing minimum-evolution trees. Mol Biol Evol 9, 945-967.

Saitou, N. \& Nei, M. (1987). The neighbor-joining method: a new method for reconstructing phylogenetic trees. Mol Biol Evol 4, 406-425.

Sawada, H. \& leki, H. (1992a). Phenotypic characteristics of the genus Agrobacterium. Ann Phytopathol Soc Japan 58, 37-45.

Sawada, H. \& leki, H. (1992b). Crown gall of kiwi caused by Agrobacterium tumefaciens in Japan. Plant Disease 76, 212 (abstract)

Sawada, H., Takikawa, Y. \& leki, H. (1992). Fatty acid methyl ester profiles of the genus Agrobacterium. Ann Phytopathol Soc Japan 58, 46-51.

Sawada, H., leki, H., Kobayashi, S. \& Oiyama, H. (1993a). Grouping of tumorigenic Agrobacterium spp. based on $\mathrm{Ti}$ plasmid-related phenotypes. Ann Phytopathol Soc Japan 58, 244-252.

Sawada, H., leki, H., Oyaizu, H. \& Matsumoto, S. (1993b). Proposal for rejection of Agrobacterium tumefaciens and revised descriptions for the genus Agrobacterium and for Agrobacterium radiobacter and Agrobacterium rhizogenes. Int J Syst Bacteriol 43, 694-702.

Sawada, H., Suzuki, F., Matsuda, I. \& Saitou, N. (1999). Phylogenetic analysis of Pseudomonas syringae pathovars suggests the horizontal gene transfer of $\arg K$ and the evolutionary stability of hrp gene cluster. J Mol Evol 49, 627-644.

Scholla, M. H. \& Elkan, G. H. (1984). Rhizobium fredii sp. nov., a fast-growing species that effectively nodulates soybeans. Int $J$ Syst Bacteriol 34, 484-486.

Segovia, L., Pinêro, D., Palacios, R. \& Martínez-Romero, E. (1991). Genetic structure of a soil population of nonsymbiotic Rhizobium leguminosarum. Appl Environ Microbiol 57, 426-433.

Segovia, L., Young, J. P. W. \& Martínez-Romero, E. (1993). Reclassification of American Rhizobium leguminosarum biovar phaseoli type I strains as Rhizobium etli sp. nov. Int J Syst Bacteriol 43, 374-377.

Selenska-Pobell, S. \& Evguenieva-Hackenberg, E. (1995). Fragmentations of the large-subunit rRNA in the family Rhizobiaceae. J Bacteriol 177, 6993-6998.

Skerman, V. B. D., McGowan, V. \& Sneath, P. H. A. (editors) (1980). Approved lists of bacterial names. Int J Syst Bacteriol 30, 225-420.

Smith, E. F. \& Townsend, C. O. (1907). A plant-tumor of bacterial origin. Science 25, 671-673.

Sneath, P. H. A. (1989). Analysis and interpretation of sequence data for bacterial systematists: the view of a numerical taxonomist. Syst Appl Microbiol 12, 15-31.

Soberón-Chávez, G. \& Nájera, R. (1989). Isolation from soil of Rhizobium leguminosarum lacking symbiotic information. Can $J$ Microbiol 35, 464-468.

Stackebrandt, E. \& Goebel, B. M. (1994). Taxonomic note: a place for DNA-DNA reassociation and $16 \mathrm{~S}$ rRNA sequence analysis in the present species definition in bacteriology. Int $J$ Syst Bacteriol 44, 846-849.

Starr, M. P. \& Weiss, J. E. (1943). Growth of phytopathogenic bacteria in a synthetic asparagine medium. Phytopathology 33, 314-318.

Süle, S. (1978). Biotypes of Agrobacterium tumefaciens in Hungary. J Appl Bacteriol 44, 207-213.

Swofford, D. L. (1993). PAUP: phylogenetic analysis using parsimony, version 3.1.1. Illinois Natural History Survey, Champaign.

Swofford, D. L., Olsen, G. J., Waddell, P. J. \& Hillis, D. M. (1996). Phylogenetic inference. In Molecular Systematics, pp. 407-514. Edited by D. M. Hillis, C. Moritz \& B. M. Mable. Sunderland, MA: Sinauer Associates.

Tamura, K. \& Nei, M. (1993). Estimation of the number of nucleotide substitutions in the control region of mitochondrial DNA in humans and chimpanzees. Mol Biol Evol 10, 512-526.

Tan, Z.-Y., Xu, X.-D., Wang, E.-T., Gao, J.-L., Martinez-Romero, E. \& Chen, W.-X. (1997). Phylogenetic and genetic relationships of Mesorhizobium tianshanense and related rhizobia. Int J Syst Bacteriol 47, 874-879.

Terefework, Z., Nick, G., Suomalainen, S., Paulin, L. \& Lindström, K. (1998). Phylogeny of Rhizobium galegae with respect to other rhizobia and agrobacteria. Int J Syst Bacteriol 48, 349-356.

Thompson, J. D., Higgins, D. G. \& Gibson, T. J. (1994). CLUSTAL $\mathrm{W}$ : improving the sensitivity of progressive multiple sequence alignment through sequence weighting, position-specific gap penalties and weight matrix choice. Nucleic Acids Res 22, 4673-4680.

Ursing, J. B., Rosselló-Mora, R. A., García-Valdés, E. \& Lalucat, J. (1995). Taxonomic note: a pragmatic approach to the nomenclature of phenotypically similar genomic groups. Int $J$ Syst Bacteriol 45, 604. 
Vandamme, P., Pot, B., Gillis, M., De Vos, P., Kersters, K. \& Swings, J. (1996). Polyphasic taxonomy, a consensus approach to bacterial systematics. Microbiol Rev 60, 407-438.

Wang, E. T., van Berkum, P., Beyene, D., Sui, X. H., Dorado, O., Chen, W. X. \& Martínez-Romero, E. (1998). Rhizobium huautlense sp. nov., a symbiont of Sesbania herbacea that has a close phylogenetic relationship with Rhizobium galegae. Int J Syst Bacteriol 48, 687-699.

Wang, E. T., van Berkum, P., Sui, X. H., Beyene, D., Chen, W. X. \& Martínez-Romero, E. (1999). Diversity of rhizobia associated with Amorpha fruticosa isolated from Chinese soils and description of Mesorhizobium amorphae sp. nov. Int $J$ Syst Bacteriol 49, 51-65.

Wayne, L. G., Brenner, D. J., Colwell, R. R. and 9 other authors (1987). Report of the ad hoc committee on reconciliation of approaches to bacterial systematics. Int J Syst Bacteriol 37, 463-464.

Weibgen, U., Russa, R., Yokota, A. \& Mayer, H. (1993). Taxonomic significance of the lipopolysaccharide composition of the three biovars of Agrobacterium tumefaciens. Syst Appl Microbiol 16, 177-182.

Wernegreen, J. J. \& Riley, M. A. (1999). Comparison of the evolutionary dynamics of symbiotic and housekeeping loci: a case for the genetic coherence of rhizobial lineages. Mol Biol Evol 16, 98-113.
White, L. O. (1972). The taxonomy of the crown-gall organism Agrobacterium tumefaciens and its relationship to rhizobia and other agrobacteria. J Gen Microbiol 72, 565-574.

Willems, A. \& Collins, M. D. (1993). Phylogenetic analysis of rhizobia and agrobacteria based on 16S rRNA gene sequences, Int J Syst Bacteriol 43, 305-313.

Xu, Y. \& Murooka, Y. (1995). A large plasmid isolated from Rhizobium huakuii bv. Renge that includes genes for both nodulation of Astragalus sinicus cv. Japan and nitrogenfixation. J Ferment Bioeng 80, 276-279.

Xu, L. M., Ge, C., Cui, Z., Li, J. \& Fan, H. (1995). Bradyrhizobium liaoningense sp. nov., isolated from the root nodules of soybeans. Int J Syst Bacteriol 45, 706-711.

Young, J. P. W. (1994). All those new names: an overview of the molecular phylogeny of plant-associated bacteria. In Advances in Molecular Genetics of Plant-Microbe Interactions, vol. 3, pp. 73-80. Edited by M. J. Daniels, J. A. Downie \& A. E. Osbourne. Dordrecht: Kluwer.

Young, J. P. W. \& Haukka, K. E. (1996). Diversity and phylogeny of rhizobia. New Phytol 133, 87-94.

Young, J. M., Takikawa, Y., Gardan, L. \& Stead, D. E. (1992). Changing concepts in the taxonomy of plant pathogenic bacteria. Annu Rev Phytopathol 30, 67-105.

Zou, X., Li, F. \& Chen, H. (1997). Characteristics of plasmids in Rhizobium huakuii. Curr Microbiol 35, 215-220. 